\title{
Bahan Ajar Elektronik Rangkaian Arus Searah bagi Siswa Kelas XII SMA: Aspek Validitas
}

\author{
Trie Rossy Handayani ${ }^{1}$, Ismet ${ }^{2}$, Saparini ${ }^{3}$ dan Ketang Wiyono ${ }^{4^{*}}$ \\ $1^{*}$ SMA PUSRI Palembang, Sumatera Selatan, \\ 2,3,4 Pendidikan Fisika FKIP Universitas Sriwijaya, Palembang, Sumatera Selatan \\ `E-mail Penulis Korespondensi: ketangw.fkipunsri@gmail.com
}

\begin{abstract}
Abstrak
Pandemic Covid-19 memberikan tantangan bagi guru untuk mampu merencanakan dan mengembangkan perangkat pembelajaran yang mampu memfasilitasi pembelajaran daring yang dilaksanakan. Tujuan penelitian ini yaitu mengetahui aspek validitas bahan ajar elektronik materi listrik arus searah (DC) bagi siswa kelas XII SMA. Penelitian ini merupakan penelitian pengembangan yang terdiri dari tahap perencanaan, pengembangan, dan evaluasi. Tahap evaluasi menggunakan tahapan evaluasi Tessmer namun hanya sampai tahap expert review. Penelitian dilaksanakan pada semester ganjil tahun ajaran 2021/2022 di SMA Pusri Palembang. Sampel penelitian yaitu siswa kelas XII IPA 1 SMA Pusri Palembang. Data dikumpulkan menggunakan lembar validasi ahli materi, desain, dan bahasa. Data yang diperoleh selanjutnya dianalisis dengan mencari rerata masing-masing aspek selanjutnya mengkategorikan kriteria kevalidannya. Hasil analisis data diperoleh hasil uji validasi ahli aspek materi, bahasa, dan desain masing-masing secara berurutan memperoleh skor $88 \%, 90 \%$, dan $98 \%$ serta semua aspek termasuk kategori sangat valid. Berdasarkan hasil tersebut maka bahan ajar elektronik materi listrik arus searah (DC) layak digunakan.
\end{abstract}

Kata kunci: bahan ajar elektronik, listrik dinamis, pengembangan bahan ajar, fisika, validitas.

\section{Abstract}

The Covid-19 pandemic presents a challenge for teachers to plan and develop learning tools to facilitate online learning. The purpose of this study is to determine the validity aspect of electronic teaching materials for direct current (DC) materials for grade XII SMA students. This research is a research and development which consists of planning, development, and evaluation stages. The evaluation stage uses the Tessmer evaluation stage but just got the expert review stage. The study was conducted in the odd semester of the 2021/2022 academic year at SMA Pusri Palembang. The research sample was students of class XII IPA 1 SMA Pusri Palembang. Data were collected using validation sheets by learning material, design and language expert,. The data obtained is then analyzed by finding the average of each aspect and then categorizing its validity criteria. The results of data analysis obtained expert validation tests on material, language, and design aspects, respectively obtaining scores of $88 \%, 90 \%$, and $98 \%$. All parts are included in the valid category. Based on these results, electronic teaching materials with direct current (DC) materials are suitable for use.

Keywords: electronic teaching materials, dynamic electricity, development of teaching materials, physics, validity.

Article History: Received: 9 November 2021

Revised : 25 November 2021

Accepted: 10 November 2021

Published: 30 November 2021

How to cite: Handayani, T.R., Ismet, Saparini, \& Wiyono Ketang. (2021). Bahan Ajar Elektronik Rangkaian Arus Searah bagi Siswa Kelas XII SMA: Aspek Validitas, Jurnal Literasi Pendidikan Fisika, 2 (2). pp. 160170. Retrieved from http://jurnal.fkip.unmul.ac.id/index.php/JLPF

Copyright (C) November 2021, Jurnal Literasi Pendidikan Fisika 
Bahan Ajar Elektronik...

\section{PENDAHULUAN}

Pandemi Covid-19 memberikan tantangan besar pada dunia pendidikan tidak tekecuali di Indonesia. Perubahan pola pembelajaran dari pembelajaran luring menjadi daring. Perubahan ini tentunya menuntut perubahan dibeberapa aspek pembelajaran mulai dari tahap perencanaan pembelajaran sampai dengan evaluasinya, khususnya pada bagian pelaksanaan pembelajaran. Pelaksanaan pembelajaran daring memerlukan perlakuan khusus terutama bagaimana menyiapkan bahan ajar yang dapat diakses kapan pun dan dimana pun oleh siswa. Namun demikian, perkembangan teknologi memberikan kemudahan bagi guru dan siswa dalam mencari sumber belajar (Saparini et al., 2021). Hal tesebut memberikan peluang bagi guru untuk mengembangkan sumber belajar yang dapat diakses secara online, salah satunya berupa bahan ajar elektronik.

Pembuatan bahan ajar elektronik yang baik sebaiknya dengan menerapkan beberapa media sekaligus. Penerapannya dalam pembelajaran fisika yaitu dengan menyajikan konsep fisika berupa gambar, grafik, teks, video, animasi, simulasi, dan sebagainya (K. Wiyono et al., 2019). Berbagai media yang digunakan diharapkan mampu mengakomodasi kebutuhan belajar siswa dikarenakan setiap siswa memiliki gaya belajar yang berbeda. Guru menganggap perbedaan gaya belajar siswa sebagai suatu hal yang istimewa sehingga perlu diberikan perlakuan istimewa agar siswa berhasil dalam proses belajarnya, meskipun melaksanakan pembelajaran melalui pembuktian ilmiah akan lebih baik (Papadatou-Pastou et al., 2021). Selain untuk mengakomodasi kebutuhan belajar siswa, bahan yang diajarkan sebaiknya mampu mengajarkan konsep yang abstrak dan sulit dipelajari serta diamati secara langsung.

Salah satu konsep fisika yang memiliki konsep bersifat abstrak yaitu materi listrik searah (DC). Hasil observasi yang dilakukan di SMA Pusri Palembang memberikan gambaran bahwa selain materi yang bersifat abstrak, di masa pandemi covid-19 ini mengharuskan peserta didik untuk melakukan pembelajaran secara Daring (dalam jaringan) menggunakan model Flipped Classroom. Di beberapa sekolah telah dilakukan Pembelajaran Tatap Muka Terbatas (PTMT) namun tidak memungkinkan bagi peserta didik untuk melakukan percobaan prinsip kerja rangkaian listrik searah (DC) secara langsung di Laboratorium. Selain kegiatan pembelajaran yang terbatas, praktikum yang berhubungan dengan listrik sangat berbahaya jika tidak diawasi langsung oleh guru. Permasalahan yang diuraikan terkait pelaksanaan percobaan prinsip kerja rangkaian arus listrik searah selanjutnya dapat dilakukan melalui pembuatan bahan ajar elektronik materi listrik searah (DC). Pembuatan bahan ajar elektronik merupakan salah satu contoh penerapan penggunaan teknologi dalam pembelajaran (Patmawati \& Kholiq, 2021).

Berdasarkan uraian yang diberikan perlu melakukan pengembangan bahan ajar elektronik materi Listrik Searah (DC) dalam membantu memenuhi indikator pencapian peserta didik pada kompetensi dasar tentang listrik dinamis di SMA kelas XII. Adapun tujuan penelitian ini yaitu untuk mengetahui aspek validitas bahan ajar elektronik materi Listrik Searah (DC). Penelitian sebelumnya terkait pengembangan bahan ajar elektronik pada berbagai konsep fisika telah dilakukan meliputi konsep suhu dan kalor (Papadatou-Pastou et al., 2021), fluida statik (Muliyati et al., 2021), fluida dinamik (Saparini et al., 2020), gelombang bunyi (Toenders et al., 2017), konsep fisika untuk kejuruan (Hakim et al., 2019), dan konsep fisika lainnya.

Adapun yang membedakan bahan ajar yang akan dikembangkan dengan bahan ajar pada penelitian sebelumnya yaitu ada video penjelasan guru tentang konsep listrik searah. Dilengkapi dengan video yang mempu membuat kesan nyata dalam pembelajaran seperti video aliran elektron pada rangkaian tertutup, video penjelasan seluruh materi di akhir ringkasan materi yang memberi kesan peserta sedang berada di dalam kelas memperhatikan guru memberikan penjelasan, dan LKPD Percobaan Hukum Kirchoff secara virtual. LKPD Hukum Kirchoff secara Virtual diberikan agar peserta didik tetap bisa melakukan percobaan secara virtual meski dimasa pandemi covid-19 dan aman dari bahaya listrik meski tidak langsung diawasi oleh guru selama melakukan percobaan. 
Bahan Ajar Elektronik...

\section{METODE}

Penelitian ini merupakan penelitian pengembangan dengan menggunakan model pengembangan Rowntree. Model pengembangan ini terdiri dari tahap perencanaan, pengembangan dan evaluasi. Tahap evaluasi menggunakan tahap evaluasi Tessmer terdiri dari slef-evaluation, expert review, oneto-one evaluation, small group evaluation, dan small group evaluation (Tessmer, 1993). Tujuan penelitian ini untuk mengetahui aspek validitas bahan ajar elektronik materi Listrik Searah (DC). Oleh sebab itu, tahap evaluasi penelitian ini dibatasi hanya sampai tahap expert review.

Penelitian ini dilaksanakan pada semester ganjil T.A. 2021/2022 di SMA Pusri Palembang. Sampel penelitian yaitu kelas XII IPA 1 SMA Pusri Palembang yang terdiri dari 32 siswa. Data penelitian dikumpulkan melalui validasi ahli dengan menggunakan instrumen lembar validasi ahli. Produk yang dikembangkan divalidasi oleh 2 orang dosen Program Studi Pendidikan Fisika masing-masing berasal dari FKIP Universitas Mulawarman dan Universitas Sriwijaya dan 1 orang guru fisika di SMA Pusri Palembang untuk memvalidasi terkait materi, bahasa, dan desain. Data diperoleh dalam bentuk data kuantitatif dan data kualitatif. Data kuantitatif diperoleh dari lembar validasi ahli yang dilaksanakan pada tahap expert review untuk mengetahui validitas bahan ajar elektronik materi Listrik Searah (DC) yang dikembangkan. Data kualitatif diperoleh dari saran dan komentar yang diberikan untuk melakukan revisi. Validitas produk dianalisis dengan mencari nilai rata-rata kemudian dikategorikan menurut tingkat validitas produk tersebut (Ketang Wiyono, 2015)(K. Wiyono et al., 2020).

\section{HASIL DAN PEMBAHASAN}

Kegiatan penelitian ini dilaksanakan bekerja sama dengan tim pengabdian masyarakat Program Studi Pendidikan Fisika FKIP Universitas Sriwijaya yang dilaksanakan pada 18 September 2021 sampai 19 Oktober 2021 melalui kegiatan pendampingan pembuatan bahan ajar elektronik bagi guruguru MGMP Fisika Provinsi Sumatera Selatan dan Bangka Belitung. Produk bahan ajar elektronik ini merupakan salah satu produk yang berhasil dikembangkan melalui kegiatan tersebut. Produk yang berhasil dikembangkan selanjutnya dilakukan uji validitas sehingga penelitian ini bertujuan untuk menguji aspek validitas produk berupa bahan ajar elektronik materi Listrik Searah (DC).

\section{HASIL}

\section{Hasil Tahap Perencanaan}

Tahap perencanaan diawali dengan analisis materi Listrik Dinamis dengan memperhatikan kompetensi dasar dan indikator pembelajaran serta sumber belajar yang diperlukan. Analisis materi disajikan dalam bentuk tabel yang menjabarkan kompetensi dasar, indikator pembelajaran, materi pembelajaran, kegiatan pembelajaran, penilaian, alokasi waktu, dan sumber belajar. Analisis materi Listrik Dinamis disajikan pada Tabel 1. 
Tabel 1. Analisis materi listrik searah (DC)

\begin{tabular}{|c|c|c|c|c|c|c|}
\hline $\begin{array}{c}\text { Kompetensi } \\
\text { Dasar }\end{array}$ & Indikator & $\begin{array}{c}\text { Materi } \\
\text { Pembelajaran }\end{array}$ & Kegiatan Pembelajaran & Penilaian & $\begin{array}{l}\text { Alokasi } \\
\text { Waktu }\end{array}$ & Sumber Belajar \\
\hline $\begin{array}{l}\text { 3.1 } \\
\text { Menganalisis } \\
\text { prinsip kerja } \\
\text { peralatan } \\
\text { listrik searah } \\
\text { (DC) berikut } \\
\text { keselamatann } \\
\text { ya dalam } \\
\text { kehidupan } \\
\text { sehari-hari } \\
\\
\text { 4.1 Melakukan } \\
\text { percobaan } \\
\text { prinsip kerja } \\
\text { rangkaian } \\
\text { listrik searah } \\
\text { (DC) dengan } \\
\text { metode ilmiah } \\
\text { berikut } \\
\text { presentasi } \\
\text { hasil } \\
\text { percobaan }\end{array}$ & $\begin{array}{ll}\text { - } & \text { Mengidentifikasi Arus } \\
\text { - } & \text { Merumuskan searah } \\
\text { - } & \text { Menyelesaikan persoalan } \\
\text { yang berkaitan dengan } \\
\text { arus listrik } \\
\text { Menyelesaikan persoalan } \\
\text { yang berkaitan dengan } \\
\text { hukum Ohm } \\
\text { Mengidentifikasi hambatan } \\
\text { - } \quad \text { Mepotong kawat } \\
\text { pengganti rangkaian seri } \\
\text { Menghitung nilai hambatan } \\
\text { pengganti rangkaian } \\
\text { paralel } \\
\text { Menerapkan hukum I } \\
\text { kirchoff } \\
\text { Menerapkan hukum II } \\
\text { kirchoff } \\
\text { Menghitung nilai energi } \\
\text { listrik } \\
\text { Menghitung nilai daya } \\
\text { listrik } \\
\text { Menyusun rangkaian } \\
\text { hambatan secara paralel } \\
\text { secara virtual } \\
\text { Membaca nilai arus pada } \\
\text { amperemeter secara } \\
\text { virtual } \\
\text { Menggambarkan grafik } \\
\text { hubungan antara arus } \\
\text { masuk dengan arus } \\
\text { keluaran dari titik } \\
\text { percabangan } \\
\text { Merumuskan hubungan } \\
\text { antara nilai hambatan dan } \\
\text { arus listrik } \\
\text { - }\end{array}$ & $\begin{array}{ll}\text { Listrik Searah ( DC ): } \\
\text { - } & \text { Arus Listrik } \\
\text { - } & \text { Hambatan } \\
& \text { sepotong kawat } \\
\text { - } & \text { Hukum Ohm } \\
\text { - } & \text { Rangkaian } \\
& \text { Hambatan } \\
\text { - } & \text { Hukum Kirchoff } \\
\text { - } & \text { Energi dan } \\
& \text { Daya Listrik }\end{array}$ & $\begin{array}{l}\text { - Memahami materi pembelajaran terkait } \\
\text { - } \quad \text { Mengtrik Searah ( DC ). } \\
\text { pemecahan masalkan pada modul terkait } \\
\text { materi Listrik Searah ( DC ). } \\
\text { - } \quad \text { Mendiskusikan materi terkait Listrik } \\
\text { - } \text { Mearah ( DC ). } \\
\text { materi Listrik Searah ( DC ). } \\
\text { - Menyelesaikan persoalan pada modul } \\
\text { terkait materi Listrik Searah ( DC ). } \\
\text { - Mengumpulkan informasi dalam } \\
\text { pemecahan masalah pada LKPD } \\
\text { berkaitan dengan materi percobaan } \\
\text { hukum kirchoff } \\
\text { Melakukan penyelidikan dari berbagai } \\
\text { sumber belajar terkait materi percobaan } \\
\text { hukum kirchoff secara virtual untuk } \\
\text { melakukan perocbaan virtual sesuai } \\
\text { petunjuk pada LKPD. } \\
\text { Melakukan percobaan hukum kirchoff } \\
\text { secara virtual pada website Phet } \\
\text { Colorado sesuai petunjuk pada LKPD } \\
\text { hukum kirchoff } \\
\text { Mendiskusikan hasil percobaan hukum } \\
\text { kirchoff secara virtual. } \\
\text { Mempresentasikan hasil percobaan } \\
\text { hukum kirchoff secara virtual. }\end{array}$ & $\begin{array}{l}\text { Praktikum } \\
\text { Persiapan } \\
\text { Pelaksanaan } \\
\text { Hasil } \\
\text { Presentasi }\end{array}$ & $2 \mathrm{JP}$ & $\begin{array}{l}\text { Sumber } \\
\text { - E-Modul Listrik } \\
\text { Searah ( DC ) } \\
\text { - LKPD } \\
\text { Percobaan } \\
\text { Virtual Hukum } \\
\text { Kirchoff } \\
\text { - Video } \\
\text { pembelajaran } \\
\text { youtube } \\
\text { "gemasics edu" } \\
\text { https://youtu.be/PtB } \\
\text { elwcPOvM }\end{array}$ \\
\hline
\end{tabular}




\section{Hasil Tahap Pengembangan}

Tahap pengembangan diawali dengan pembuatan storyboard. Storyboard bahan ajar elektronik arus listrik searah (DC) disajikan pada Tabel 2 berikut.

Tabel 2. Storyboard bahan ajar elektronik arus listrik searah (DC)

\begin{tabular}{|c|c|c|c|c|c|}
\hline No & JUDUL & $\begin{array}{l}\text { HALAMAN } \\
\text { KE- }\end{array}$ & NAMA HALAMAN & KETERANGAN & MEDIA \\
\hline 1 & Arus Listrik Searah & 1 & Halaman Sampul & $\begin{array}{l}\text { Terdapat judul } \\
\text { "Bahan Ajar } \\
\text { Elektronik Arus } \\
\text { Searah (DC)", } \\
\text { identitas penulis, } \\
\text { chanel youtube } \\
\text { penulis, serta } \\
\text { gambat yang } \\
\text { berhubungan } \\
\text { dengan listrik }\end{array}$ & $\begin{array}{l}\text { Gambar kabel listrik, } \\
\text { penampang IC, } \\
\text { gambar symbol } \\
\text { youtube bertuliskan } \\
\text { "gemasics edu". } \\
\text { Tulisan "Bahan Ajar } \\
\text { Elektronik Arus Searah } \\
\text { (DC)" berwarna hitam } \\
\text { dengan latar nude } \\
\text { gelap }\end{array}$ \\
\hline 2 & & 2 & Kompetensi Dasar & $\begin{array}{l}\text { halaman yang } \\
\text { berisi kompetensi } \\
\text { dasar dan indikator } \\
\text { pencapaian } \\
\text { kompetensi dari } \\
\text { materi yang akan } \\
\text { dikembangkan. } \\
\text { Terdapat halaman } \\
\text { dari bahan ajar di } \\
\text { lengkapi channel } \\
\text { youtube penulis }\end{array}$ & Tidak ada \\
\hline 3 & & 3 & Arus Listrik & $\begin{array}{l}\text { Halaman ketiga } \\
\text { terdapat tulisan } \\
\text { listrik dinamis, arus } \\
\text { searah, pengertian } \\
\text { arus searah dan } \\
\text { rumus arus listrik }\end{array}$ & $\begin{array}{l}\text { Video aliran electron } \\
\text { dan aliran arus listrik }\end{array}$ \\
\hline 4 & & 4 & Hukum Ohm & $\begin{array}{l}\text { Halaman keempat } \\
\text { terdapat tulisan } \\
\text { hukum ohm, bunyi } \\
\text { hukum ohm, } \\
\text { pengertian dan } \\
\text { rumus hambatan } \\
\text { sepotong kawat } \\
\text { serta keterangan } \\
\text { dari rumus hukum } \\
\text { ohm dan hambatan } \\
\text { sepotong kawat }\end{array}$ & $\begin{array}{l}\text { Simbol-simbol yang } \\
\text { sering digunakan pada } \\
\text { diagram rangkaian } \\
\text { listrik di dalam } \\
\text { persoalan fisika }\end{array}$ \\
\hline 5 & & 5 & Rangkaian Seri & $\begin{array}{l}\text { Halaman lima } \\
\text { berisi penjelasan } \\
\text { dan rumus dari } \\
\text { rangkaian } \\
\text { hambatan secara } \\
\text { seri, video } \\
\text { pendukung } \\
\text { rangkaian seri, dan } \\
\text { penjelasan video }\end{array}$ & $\begin{array}{l}\text { Video yang } \\
\text { menampilkan nilai arus } \\
\text { listrik pada lampu yang } \\
\text { dirangkai secara seri }\end{array}$ \\
\hline 6 & & 6 & Rangkaian Paralel & $\begin{array}{l}\text { Halaman lima } \\
\text { berisi penjelasan } \\
\text { dan rumus dari } \\
\text { rangkaian } \\
\text { hambatan secara } \\
\text { paralel, video } \\
\text { pendukung } \\
\text { rangkaian seri, dan } \\
\text { penjelasan video }\end{array}$ & $\begin{array}{l}\text { Video yang } \\
\text { menampilkan nilai arus } \\
\text { listrik pda lampu yang } \\
\text { dirangkai secara } \\
\text { paralel }\end{array}$ \\
\hline 7 & & 7 & Hukum I Krichoff & $\begin{array}{l}\text { Halaman tujuh } \\
\text { berisi penjelasan }\end{array}$ & $\begin{array}{l}\text { Video yang } \\
\text { menampilkan nilai arus }\end{array}$ \\
\hline
\end{tabular}


Bahan Ajar Elektronik...

\begin{tabular}{|c|c|c|c|c|}
\hline & & & $\begin{array}{l}\text { tentang hukum I } \\
\text { kirchoff yang } \\
\text { dilengkapi video } \\
\text { rangkian parale }\end{array}$ & $\begin{array}{l}\text { listrik pada lampu } \\
\text { masing-masing yang } \\
\text { dirangkai secara } \\
\text { parelel dan nilai arus } \\
\text { keseluran yang } \\
\text { mengalir pada } \\
\text { rangkaian }\end{array}$ \\
\hline 8 & 8 & Hukum II Krichoff & $\begin{array}{l}\text { Halaman delapan } \\
\text { berisi penjelasan } \\
\text { tentang hukum II } \\
\text { Kirchoff dilengkapi } \\
\text { dengan penjelasan } \\
\text { penyelesaian so }\end{array}$ & $\begin{array}{l}\text { Gambar arah loop } \\
\text { yang searah dan } \\
\text { berlawanan arah } \\
\text { dengan arah arus, dan } \\
\text { gambar arah loop yang } \\
\text { nemabrak kutub } \\
\text { positip dan kutub } \\
\text { negatif pada sumber } \\
\text { tegangan ran }\end{array}$ \\
\hline 9 & 9 & $\begin{array}{l}\text { Energi dan Daya } \\
\text { Listrik }\end{array}$ & $\begin{array}{l}\text { Halaman sembilan } \\
\text { berisi penjelasan } \\
\text { dan rumus dari } \\
\text { energi dan daya } \\
\text { listrik dan video } \\
\text { penjelasan seluruh } \\
\text { materi }\end{array}$ & $\begin{array}{l}\text { Video yang } \\
\text { menampilkan } \\
\text { penjelasan rangkaian } \\
\text { arus searah yang } \\
\text { didukung dari channel } \\
\text { youtube gemasics edu }\end{array}$ \\
\hline 10 & 10 & Penjelasan materi & $\begin{array}{l}\text { Halaman sembilan } \\
\text { berisi video } \\
\text { penjelasan materi } \\
\text { hukum kirchoff dan } \\
\text { penjelsan energi } \\
\text { dan daya listrik }\end{array}$ & $\begin{array}{l}\text { Video yang } \\
\text { menampilkan } \\
\text { penjelasan hukum } \\
\text { kirchoff dan energi dan } \\
\text { daya listrik yang } \\
\text { didukung dari channel } \\
\text { youtube gemasics edu }\end{array}$ \\
\hline 11 & 11 & Lembar Kerja & $\begin{array}{l}\text { Halaman sebelas } \\
\text { berisi lembar kerja } \\
\text { peseta didik yang } \\
\text { terdapat } \\
\text { kompetensi dasar, } \\
\text { tujuan praktikum, } \\
\text { hipotesa dan } \\
\text { prosedur } \\
\text { percobaan }\end{array}$ & $\begin{array}{l}\text { Gambar rangkaian } \\
\text { yang akan digunakan } \\
\text { pada percobaan arus } \\
\text { listrik searah materi } \\
\text { hukum kirchoff secara } \\
\text { virtual }\end{array}$ \\
\hline 12 & 12 & Lembar Kerja & $\begin{array}{l}\text { Halaman dua belas } \\
\text { berisi tabel hasil } \\
\text { pengamatan, } \\
\text { analisa berupa } \\
\text { grafisk hubungan } \\
\text { arus masuk dan } \\
\text { arus keluaran, } \\
\text { kesimpulan } \\
\text { praktikum }\end{array}$ & Tidak ada \\
\hline 13 & 13 & Daftar Pustaka & $\begin{array}{l}\text { Halaman duabelas } \\
\text { berisi daftar pustak } \\
\text { a yang digunakan } \\
\text { penulis untuk } \\
\text { membantu } \\
\text { pengembahan } \\
\text { bahan ajar }\end{array}$ & Tidak ada \\
\hline
\end{tabular}

\section{Hasil Tahap Evaluasi}

Hasil tahap evaluasi terdiri dari hasil tahap self-evaluation dan expert review. Tahap self-evaluation dilakukan oleh peneliti untuk memeriksa kembali prototype bahan ajar elektronik materi Listrik Searah (DC) untuk selanjutnya dilakukan expert review untuk memperoleh informasi terkait aspek validitas produk. Berdasarkan hasil self-evaluation, peneliti menyimpulkan bahwa prototype yang dikembangkan 
Bahan Ajar Elektronik...

telah sesuai dengan storyboard yang telah dibuat sebelumnya baik aspek materi dan media yang digunakan dan selanjutnya disebut sebagai prototype I. Gambar 1 menunjukkan prototype I bahan ajar elektronik materi Listrik Searah (DC) sebelum dilanjutkan ke tahap expert review.

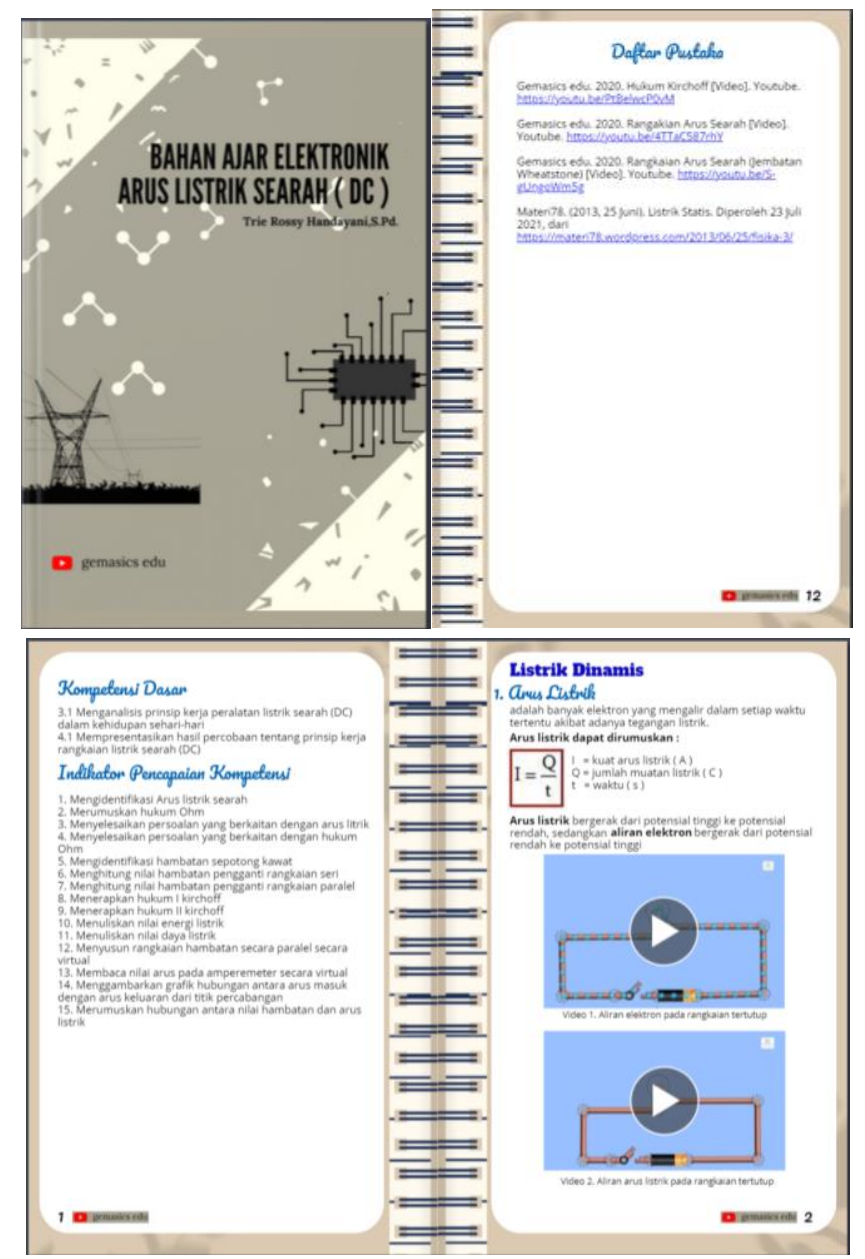

Gambar 1 Prototype / bahan ajar elektronik materi Listrik Searah (DC)

Tahap selanjutnya yaitu tahap expert review yang berkaitan dengan validitas aspek materi, desain, dan bahasa. Komentar dan saran hasil expert review selanjutnya digunakan sebagai dasar revisi prototype I dan setelah revisi selanjutnya disebut sebagai prototype // bahan ajar elektronik materi Listrik Searah (DC). Salah satu saran yang diberikan berkaitan dengan validasi desain dan bahasa yaitu perlunya tambahan keterangan penyerta atau sebelum video ditampilkan sehingga dapat membantu pemahaman siswa. Hal senada juga diberikan dari hasil validasi materi khususnya pada bagian arus listrik, dimana perlu ada penjelasan tambahan sebelum atau sesudah video yang menunjukkan arah aliran electron dan arus listrik. Rekapitulasi hasil expert review masing-masing aspek disajikan pada Tabel 3.

Tabel 3. Rekapitulasi hasil expert review

\begin{tabular}{cccc}
\hline URAIAN & Materi & Desain & Bahasa \\
\hline Persentase & $88 \%$ & $90 \%$ & $98 \%$ \\
\hline Kategory & sangat valid & sangat valid & sangat valid \\
\hline
\end{tabular}

\section{PEMBAHASAN}

Pandemic Covid-19 menuntut kreatifitas guru dalam mengajar salah satunya yaitu mampu merencanakan dan mengembangkan bahan ajar sendiri yang dapat diakses oleh siswa dimana dan kapan saja. Masalah tersebut mendorong Program Studi Pendidikan Fisika FKIP Universitas Sriwijaya melakukan kegiatan pengabdian masyarakat berupa pendampingan pembuatan bahan ajar dan media 
Bahan Ajar Elektronik...

pembelajaran berbasis blended learning yang dilaksanakan tanggal 18 September 2021 sampai 19 Oktober 2021. Bahan ajar elektronik Listrik Searah (DC) ini merupakan salah satu produk dari kegiatan tersebut. Bahan ajar elektronik Listrik Searah (DC) yang dikembangkan diharapkan selanjutnya dapat dimanfaatkan dalam proses belajar mengajar di SMA khususnya SMA Pusri Palembang.

\section{Tahap Perencanaan}

Tahap perencanaan pada penelitian ini diawali dengan analisis kebutuhan berupa analisis materi Listrik Searah (DC) yang disajikan pada Tabel 1. Tabel 1 menunjukkan bahwa bahwa materi Listrik Searah (DC) memiliki beberapa materi yang bersifat abstrak (tidak dapat dilihat secara langsung). Selain materi yang bersifat abstrak, di masa pandemi covid-19 ini mengharuskan peserta didik untuk melakukan pembelajran secara Daring menggunakan model Flipped Classroom. Beberapa sekolah telah dilakukan Pembelajaran Tatap Muka Terbatas (PTMT) namun tidak memungkinkan bagi peserta didik untuk melakukan percobaan prinsip kerja rangkaian listrik serah (DC) sesuai dengan kompetensi dasar 4.1 secara langsung di dalam Laboratorium. Selain kegiatan pembelajaran yang terbatas, praktikum yang berhubungan dengan listrik sangat berbahaya jika tidak diawasi langsung oleh guru.

Berdasarkan uraian tersebut perlu adanya bahan ajar elektronik Listrik Searah (DC) dalam membantu memenuhi indikator pencapaian peserta didik pada kompetensi dasar 3.1 dan 4.1. E-Modul yang dikembangkan dapat diakses oleh peserta didik secara online, dimana saja, dan kapan saja. EModul akan menampilkan ringakasan materi penting yang mempu membimbing peserta didik dalam menyelesaikan persoalan yang berhubungan dengan materi Listrik Searah ( DC ). Dilengkapi dengan video yang mempu membuat kesan nyata dalam pembelajaran seperti video aliran elektron pada rangkaian tertutup, video penjelasan seluruh materi di akhir ringkasan materi yang memberi kesan peserta sedang berada di dalam kelas memperhatikan guru memberikan penjelasan, dan LKPD Percobaan Hukum Kirchoff secara virtual. LKPD Hukum Kirchoff secara Virtual diberikan agar peserta didik tetap bisa melakukan percobaan secara virtual meski dimasa pandemi covid-19 dan aman dari bahaya listrik meski tidak langsung diawasi oleh guru selama melakukan percobaan.

\section{Tahap Pengembangan}

Tahap pengembangan dilakukan berdasarkan storyboard yang telah dibuat sebelumnya dan disajikan pada Tabel 2. Tabel 2 bukan sekedar menunjukkan apa saja isi pada masing-masing bahan ajar elektronik yang dikembangkan namun juga terdapat media yang digunakan. Sebagai contoh pada penjelasan mengenai arah electron dan arus listrik pada rangkaian tertutup, pada bagian tersebut disajikan menggunakan video yang merupakan rekaman dari simulasi arah gerak electron dan arus listrik dengan memanfaatkan simulasi materi listrik searah yang dikembangkan oleh phet.colorado.edu (Phet Interactive Simulation, n.d.).

Penelitian sebelumnya yang memanfaatkan simulasi yang dikembangkan oleh phet.colorado.edu telah dilaksanakan. Beberapa penelitian tersebut antara lain penggunaan phet untuk pengajaran fisika (Wieman et al., 2010), penggunaan media phet untuk mengetahui profil kemampuan berpikir tingkat tinggi siswa pada pembelajaran fisika (Yusuf \& Widyaningsih, 2019), penggunaan phet untuk meningkatkan kemampuan proses sains (Haryadi \& Pujiastuti, 2020), pelaksanaan praktikum fisika secara virtual laboratory menggunakan simulasi phet (Saparini et al., 2016), dan sebagainya. Namun demikian, yang membedakan bahan ajar elektronik materi Listrik Searah (DC) ini dengan penelitian sebelumnya terletak pada adanya video yang berisi penjelasan teori yang dibuat sedemikian rupa sehingga mirip dengan penjelasan guru di kelas. Pada bagian ini siswa akan diberikan pengalaman seolah-olah mendengarkan guru menjelaskan materi. Tampilan video penjelasan ini disajikan pada Gambar 2 berikut. 
Bahan Ajar Elektronik...
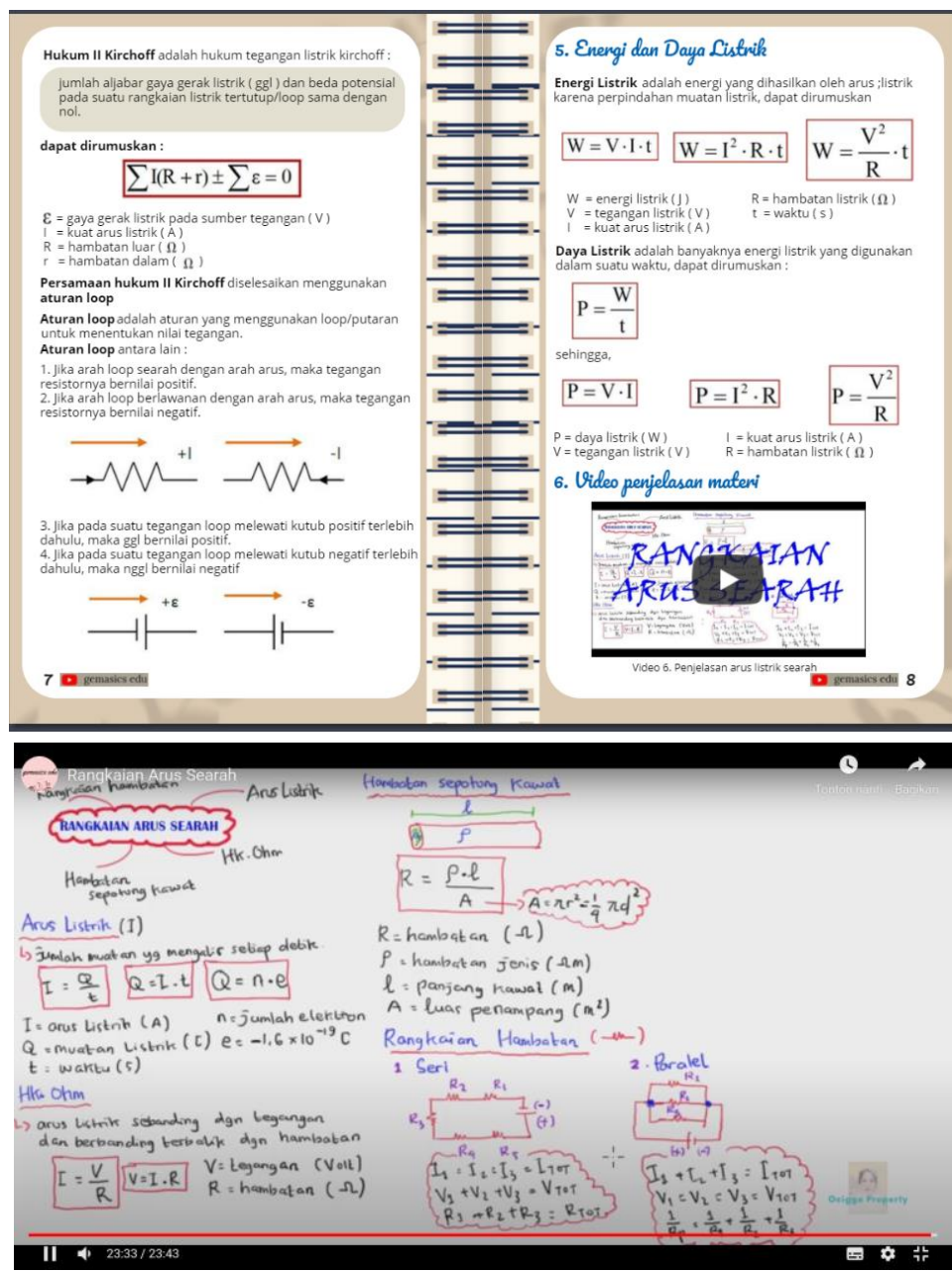

Gambar 2 tampilan video penjelasan rangkaian arus searah

\section{Tahap Evaluasi}

Tahap evaluasi dilakukan untuk memperoleh validitas bahan ajar elektronik Listrik Searah (DC). Suatu bahan ajar sebaiknya perlu dilakukan uji kelayakan terlebih dahulu sebelum digunakan (Zakaria et al., 2020). Selain itu, bahan ajar perlu diuji validitasnya untuk mengetahui kualitas bahan ajar tersebut (Putra et al., 2018). Hasil yang diperoleh pada tahap evaluasi menunjukkan bahwa baik aspek materi, desain, maupun bahasa masing-masing termasuk kategori sangat valid. Suatu bahan ajar dinyatakan layak jika memiliki kriteria nilai tinggi (Zakaria et al., 2020). Berdasarkan pendapat tersebut, bahan ajar elektronik Listrik Searah (DC) dapat dikatakan layak digunakan.

Hasil penelitian yang diperoleh merupakan modifikasi dari penelitian sebelumnya yang berkaitan dengan bahan ajar elektronik materi kelistrikan. Penelitian tersebut antara lain pengembangan e-modul berbasis web untuk materi listrik statis dan dinamis (Solihudin $\mathrm{JH}, 2018$ ), pengembangan e-modul dasar-dasar listrik dan elektronika (Pazlina \& Usmeldi, 2020), pengembangan bahan ajar elektronik berbasis android materi listrik statis (Pazlina \& Usmeldi, 2020), dan sebagainya. Namun demikian, masing-masing bahan ajar yang telah dikembangkan sebelumnya dikembangkan berdasarkan analisis kebutuhan tertentu dan berbeda dengan analisis kebutuhan perlunya bahan ajar elektronik materi Listrik Searah (DC) yang telah dikembangkan. Telah diuraikan sebelumnya bahwa hasil analisis materi yang disajikan tabel 1 menunjukkan perlu adanya bahan ajar yang mampu mengajarkan seluruh komptensi dasar dari materi listrik searah meskipun siswa harus belajar mandiri melalui media yang dikembangkan. 
Bahan Ajar Elektronik...

\section{PENUTUP}

Berdasarkan pembahasan hasil penelitian yang telah dilaksanakan disimpulkan bahwa bahan ajar elektronik materi Listrik Searah (DC) layak digunakan. Hal ini dikarenakan hasil uji validasi ahli aspek materi, bahasa, dan desain masing-masing secara berurutan memperoleh skor $88 \%$, 90\%, dan $98 \%$ serta semua aspek termasuk kategori sangat valid. Hasil penelitian ini tentunya belum mampu memberikan informasi menyeluruh terkait manfaat produk yang dikembangan sehingga perlu dilakukan penelitian lanjutan untuk menguji efektifitas bahan ajar elektronik materi listrik searah ini dalam pembelajaran.

\section{DAFTAR PUSTAKA}

Hakim, S. R., Kustijono, R., \& Wiwin, E. (2019). The use of android-based teaching materials in physics learning process at vocational high school. Journal of Physics: Conference Series, 1171(1). https://doi.org/10.1088/1742-6596/1171/1/012024

Haryadi, R., \& Pujiastuti, H. (2020). PhET simulation software-based learning to improve science process skills. Journal of Physics: Conference Series, 1521(2). https://doi.org/10.1088/1742$6596 / 1521 / 2 / 022017$

Muliyati, D., Rahmah, A., Sunaryo, S., \& Susanti, D. (2021). The development of Android-based physics teaching materials on static fluids. AIP Conference Proceedings, 2331(April). https://doi.org/10.1063/5.0041764

Papadatou-Pastou, M., Touloumakos, A. K., Koutouveli, C., \& Barrable, A. (2021). The learning styles neuromyth: when the same term means different things to different teachers. European Journal of Psychology of Education, 36(2), 511-531. https://doi.org/10.1007/s10212-020-00485-2

Patmawati, T., \& Kholiq, A. (2021). Development of 3D E-FIST as A Teaching Material for E-Learning on Temperature and Heat Materials. Jurnal IImiah Pendidikan Fisika, 5(1), 70. https://doi.org/10.20527/jipf.v5i1.2854

Pazlina, N., \& Usmeldi. (2020). Pengembangan E-Modul Dasar-dasar Listrik dan Elektronika Berbasis Problem-Based Learning. Jurnal Pendidikan Teknik Elektro, 1(1), 71-74.

Phet Interactive Simulation. (n.d.). University of Colorado. https://phet.colorado.edu/

Putra, A., Syarifuddin, H., \& Zulfah, Z. (2018). Validitas Lembar Kerja Peserta Didik Berbasis Penemuan Terbimbing dalam Upaya Meningkatkan Pemahaman Konsep dan Kemampuan Penalaran Matematis. Edumatika: Jurnal Riset Pendidikan Matematika, 1(2), 56. https://doi.org/10.32939/ejrpm.v1i2.302

Saparini, S., Syuhendri, S., \& Murniati, M. (2021). Conceptual Change Textbook Based on Local Wisdom of Palembang on Heat and Temperature. Berkala Ilmiah Pendidikan Fisika, 9(1), 88. https://doi.org/10.20527/bipf.v9i1.9568

Saparini, S., Wiyono, K., \& Ismet, I. (2016). Inkuiri Untuk Melaksanakan Praktikum Secara Virtual. Berkala Ilmiah Pendidikan Fisika, 6(1), 1-17.

Saparini, S., Wiyono, K., \& Muslim, A. B. (2020). Development of Dinamic Fluid Learning Video Based on Contextual in Water Area for High School Students. Berkala IImiah Pendidikan Fisika, 8(2), 117. https://doi.org/10.20527/bipf.v8i2.8281

Solihudin JH, T. (2018). Pengembangan E-Modul Berbasis Web Untuk Meningkatkan Pencapaian Kompetensi Pengetahuan Fisika Pada Materi Listrik Statis Dan Dinamis Sma. WaPFi (Wahana Pendidikan Fisika), 3(2), 51. https://doi.org/10.17509/wapfi.v3i2.13731

Tessmer, M. (1993). Planning and Conducting Formative Evaluations (1st Editio). Routledge. https://doi.org/https://doi.org/10.4324/9780203061978

Toenders, F. G. C., de Putter-Smits, L. G. A., Sanders, W. T. M., \& den Brok, P. (2017). Improving physics teaching materials on sound for visually impaired students in high school. Physics Education, 52(5), 55006. https://doi.org/10.1088/1361-6552/aa7969

Wieman, C. E., Adams, W. K., Loeblein, P., \& Perkins, K. K. (2010). Teaching Physics Using PhET Simulations. The Physics Teacher, 48(4), 225-227. https://doi.org/10.1119/1.3361987

Wiyono, K., Ismet, I., Noprianti, N., Permawati, H., Saparini, S., \& Zakiyah, S. (2019). Interactive multimedia using multiple-intelligences-based in the lesson of thermodynamics for high school. Journal of Physics: Conference Series, 1166(1). https://doi.org/10.1088/1742$6596 / 1166 / 1 / 012014$

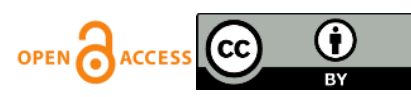


Bahan Ajar Elektronik...

Wiyono, K., Ismet, I., \& Saparini, S. (2020). Development of interactive multimedia for learning physics based on traditional games. Journal of Physics: Conference Series, 1480(1). https://doi.org/10.1088/1742-6596/1480/1/012074

Wiyono, Ketang. (2015). Pengembangan Model Pembelajaran Fisika Berbasis Ict Pada Implementasi Kurikulum 2013. Jurnal Inovasi Dan Pembelajaran Fisika, 2(2), 123-131. https://doi.org/10.36706/jipf.v2i2.2613

Yusuf, I., \& Widyaningsih, S. W. (2019). HOTS profile of physics education students in STEM-based classes using PhET media. Journal of Physics: Conference Series, 1157(3). https://doi.org/10.1088/1742-6596/1157/3/032021

Zakaria, L. M. A., Purwoko, A. A., \& Hadisaputra, S. (2020). Pengembangan Bahan Ajar Kimia Berbasis Masalah Dengan Pendekatan Brain Based Learning: Validitas dan Reliabilitas. Jurnal Pijar Mipa, 15(5), 554. https://doi.org/10.29303/jpm.v15i5.2258 